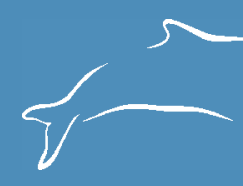

\title{
Behavior and habitat use of released rehabilitated Amazonian manatees in Peru
}

\section{Article Info}

\begin{tabular}{|c|c|}
\hline Manuscript type & Article \\
\hline \multicolumn{2}{|l|}{ Article history } \\
\hline Received & 03 June 2015 \\
\hline Received in revised form & 07 November 2015 \\
\hline Accepted & 02 February 2016 \\
\hline Available online & 30 December 2017 \\
\hline \multicolumn{2}{|c|}{$\begin{array}{l}\text { Keywords: habitat selection, post-release monitoring, radio } \\
\text { tracking, Trichechus inunguis, daytime behavior, Centro de Rescate } \\
\text { Amazónico }\end{array}$} \\
\hline \multicolumn{2}{|c|}{ Responsible Editor: Daniel Gonzalez-Socoloske } \\
\hline \multicolumn{2}{|c|}{$\begin{array}{l}\text { Citation: Landeo-Yauri, S., Castelblanco-Martínez, N. and } \\
\text { Williams, M. (2017) Behavior and habitat use of released rehabilitated } \\
\text { Amazonian manatees in Peru. Latin American Journal of Aquatic } \\
\text { Mammals 12(1-2): 17-27. https://doi.org/10.5597/lajam00234 }\end{array}$} \\
\hline
\end{tabular}

\section{Sarah Landeo-Yaurit ${ }^{\dagger,}$, Nataly Castelblanco- Martínez $^{\ddagger, \mathbb{S}}$ and Martha Williams}

${ }^{\dagger}$ Centro de Rescate Amazónico (CREA). Carretera Iquitos-Nauta, km 4.5, Iquitos, Peru

* Consejo Nacional de Ciencia y Tecnología, Universidad de Quintana Roo, Departamento de Ciencias e Ingeniería. Bulevar Bahía s/n esq. Ignacio Comonfort del Bosque, 77019 Chetumal, Quintana Roo, Mexico ${ }^{\S}$ FINS (Fundación Internacional para la Naturaleza y la Sostenibilidad). Calle Larún Manzana 75, lote 4, 75014 Andara, Chetumal, Quintana Roo, Mexico

'Departamento de Biología, Universidad Nacional Agraria la Molina. Av. La Molina s/n, Lima, Peru

*Corresponding author, e-mail: sslandeo@gmail.com

Abstract. The Amazonian manatee (Trichechus inunguis) is endangered due to illegal hunting. In Peru, the Centro de Rescate Amazónico (CREA) rehabilitates and releases rescued manatees. Three females and two males were released in El Dorado Lake in July 2011 and radio tracked until November 2011. Movements, habitat use and behavior recorded during the post-release period were used to evaluate the manatees' adaptation to free-living conditions. A total of 140 locations was registered during 91 days of tracking. Females showed greater residence time than males, which migrated out of the lake. Females selectively used the micro habitats of the study area, preferring floating vegetation, followed by open water and lastly shore macrophytes. Most idling behaviors were registered in areas with floating macrophytes, and open water was mainly used for traveling. No correlation between sighting hour and sighting location (micro habitat type) was detected. The use of suitable zones, in addition to natural behavior, suggests that these rescued manatees responded well to free-living conditions after release. Some considerations are provided with the purpose of strengthening manatee rehabilitation programs and improving future releases, emphasizing the importance of choosing appropriate individuals, as well as suitable areas and times to help improve release outcome.

Resumen. El manatí amazónico (Trichechus inunguis) es una especie amenazada, principalmente debido a la caza ilegal. En Perú, el Centro de Rescate Amazónico (CREA) desarrolla esfuerzos para rehabilitar manatíes rescatados y liberarlos posteriormente a la vida silvestre. Tres hembras y dos machos fueron liberados en la cocha El Dorado en julio del 2011, siendo rastreados mediante telemetría VHF hasta noviembre del mismo año. El monitoreo post liberación incluyó el registro de los desplazamientos, uso de hábitat y comportamiento de los animales, con el fin de evaluar su adaptación a las condiciones de vida libre. A lo largo de 91 días de rastreo, se obtuvo un total de 140 localizaciones. Las hembras mostraron un mayor tiempo de residencia que los machos, quienes migraron fuera de la zona de liberación. También se determinó que las hembras usaron selectivamente los micro habitats en el área de estudio, prefiriendo zonas de vegetación flotante seguidas por aguas abiertas y finalmente orillas asociadas a vegetación. La mayoría de desplazamientos fueron observados en aguas abiertas, mientras que comportamientos de permanencia ocurrieron generalmente en vegetación flotante. No se encontró ninguna correlación entre el tipo de micro habitat ocupado y la hora del día. El uso selectivo de zonas adecuadas por parte de los individuos, sumado a reportes previos sobre el comportamiento de la especie en vida silvestre, sugiere que los manatíes liberados tuvieron una respuesta positiva a las condiciones del medio natural. Se incluyen algunas recomendaciones con el fin de fortalecer programas de rehabilitación y mejorar futuras liberaciones, enfatizando la importancia de seleccionar adecuadamente los individuos a ser liberados, así como las áreas y tiempos de liberación. 


\section{Introduction}

The Amazonian manatee (Trichechus inunguis) is the only exclusively freshwater sirenian, endemic to the Amazonian region and one of the largest mammals in South America (Timm et al., 1986; Rosas, 1994). A long history of commercial exploitation (Domning, 1982), combined with low reproductive rates and habitat degradation, has seriously reduced the current population (Rosas, 1994). The species is listed as Vulnerable in the IUCN Red List (IUCN, 2014), in the CITES appendix since $1973^{1}$, and in the appendix II of the Convention on the Conservation of Migratory Species of Wild Animals since 2002 (CMS, 2012). Many aspects of its distribution and ecology are unknown, because of the inherent difficulties of monitoring wild manatee populations; including low population densities, low detectability in the waters they occupy, elusive behavior, and low frequency of surface behaviors (Castelblanco-Martínez, 2004). Radio tracking is a practical solution to monitoring Amazonian manatees in order to overcome these issues (Montgomery et al., 1981; Martin and Da Silva, 1998).

In Peru, most efforts to conserve Amazonian manatees are carried out by Centro de Rescate Amazónico (CREA), which is devoted to the rescue, rehabilitation, and subsequent release of manatees. Successful releases, resulting in reproduction, assist the wild population with additional genes introduced into the remaining population, thereby increasing genetic diversity (IUCN/SSC, 2013). Through conservation and rehabilitation programs in Brazil, Colombia, and Peru, it has been possible to release more than 30 Amazonian manatees, to the date of this publication ${ }^{2}$.

Post-release monitoring allows managers to respond promptly if the animal needs assistance and is essential to evaluate the success of a translocation process, defined as the human-mediated movement of living organisms from one area, with release in another (IUCN/SSC, 2013). Long-term monitoring, combined with ecological studies of the wild population, can indicate how quickly released animals achieve a behavioral repertoire comparable to wild individuals relative to foraging behavior, movements, and habitat use, and how changes may occur. Regular surveys of a manatee's status help to assess the release effects on the wild population.

Finally, in the unfortunate case of a manatee death, intensive follow-up allows the collection of the carcasses for pathological studies to elucidate the cause of death (Kleiman, 1989). We present and discuss the results of the monitoring of five Amazonian manatees after rehabilitation and release in Peru, with emphasis on their habitat preferences and behavior. This is the first effort in Peru to follow in detail the post-release performance of Amazonian manatees after successful rehabilitation.

${ }^{1}$ Soini, P., Sicchar, L.A., Gil, G., Fachín, A., Pezo, R. and Chumbe, M. (1996) Una evaluación de la fauna silvestre y su aprovechamiento en la Reserva Nacional Pacaya Samiria. Documento Tecnico $N^{\circ} 24$, Instituto de Investigación de la Amazonía Peruana/IIAP, August 1996, Iquitos, Peru. 64 pp. [Available online at <http://www.iiap.org.pe/Upload/Publicacion/ ST024.pdf>]

${ }^{2}$ D.N. Castelblanco-Martínez, pers. comm.

\section{Materials and Methods}

Study area

El Dorado Lake (Figure 1) is within the Pacaya Samiria National Reserve (PSNR) $\left(05^{\circ} 04^{\prime} S, 74^{\circ} 19^{\prime} \mathrm{W}\right)$. The lake covers an area of $463 \mathrm{ha}$, with a perimeter of $30217 \mathrm{~m}$, and provides the headwaters of the Yanayacu Pucate River, a tributary of the Marañón River. The lake has three main water channels: Llanchama, Anuncho and Dorado, the latter acting as an outlet. The depth varies from $0.4 \mathrm{~m}$ to $1.8 \mathrm{~m}$ during the dry season (June to October), and up to $8.0 \mathrm{~m}$ during the rainy season (November to May) (Rojas et al., 2006; Vásquez and Tovar, 2007). Currently, 'Yacu Tayta' (a social organization of artisanal fishermen and processors) manages and protects the aquatic resources of the lake. The release site is within the range of the species, and is within a natural protected area, as suggested for appropriate wildlife conservation release protocols (Castelblanco-Martínez, 2013; IUCN/SSC, 2013).

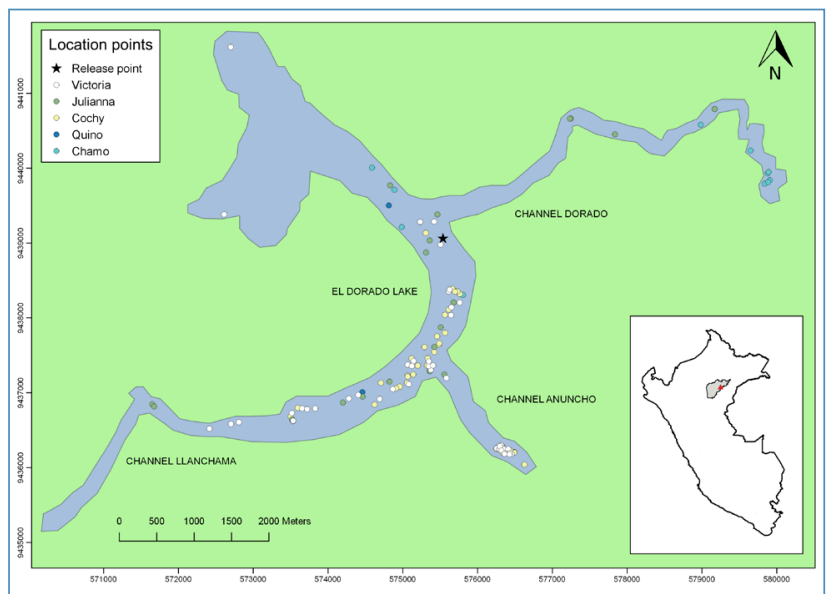

Figure 1. Post-release location points of manatees.

The available habitat in the release area can be divided into three distinct components, characterized by the aquatic vegetation structure: shore macrophytes, floating macrophytes and open water (Figure 2). For practical effects, we will refer to them as 'micro habitats', considering micro habitat as a finer division of an animal's space use that occurs within its normal daily range (Barrows, 2001). Shore macrophytes consist of vegetation associated to the lake edges mainly composed by patches of rooted macrophytes, but floating vegetation can be present in small patches when tangling on the edges of the lake. Floating macrophytes include floating plants (generally shore macrophytes that are dragged by water from the shores) or meadows not associated to lake edges and typically on deep waters. Open water includes the surface that is not occupied by shore macrophytes or floating macrophytes.

\section{Selection of individuals, transportation and release}

The manatees chosen for release were two males (Chamo and Quino) and three females (Victoria, Julianna, and Cochy) rescued from black market, fish farms, or recreational 

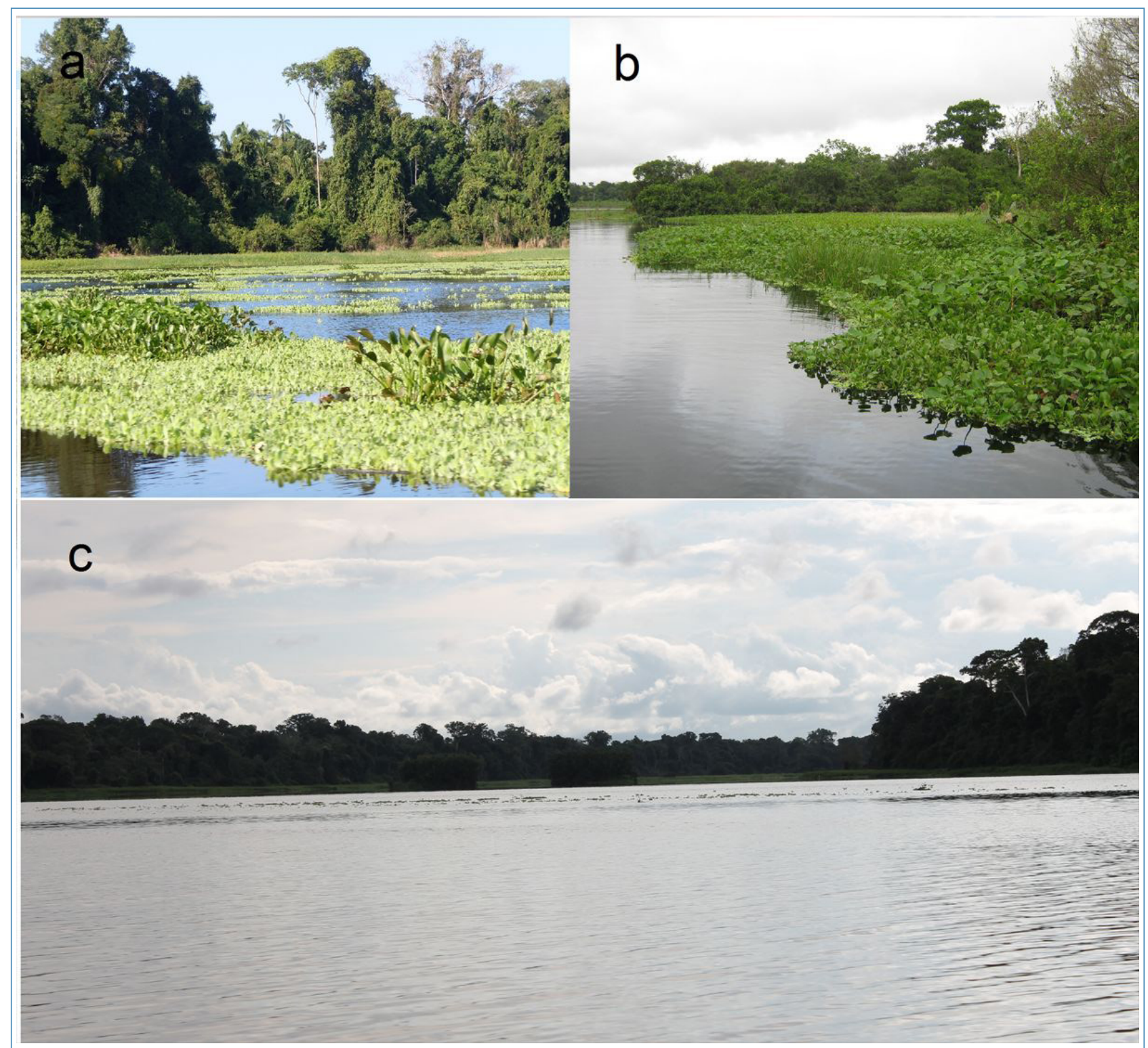

Figure 2. Micro habitat (a) floating macrophytes, (b) shore macrophytes, (c) and open water.

centers where they were kept as pets (Table 1). Manatees were rehabilitated at CREA, where veterinary treatment and specific feeding protocols were tailored to individual needs (PereaSicchar $e t$ al., 2011). At the time of release, the individuals had surpassed two and a half years of age and were no longer dependent on milk in their diet (Marmontel et al., 1992). The diet during captivity was mainly composed of water lettuce (Pistia stratiotes). Human contact was avoided after weaning in the case of manatees that were rescued as calves or after quarantine in the case of those individuals that came to the rescue center as adults or juveniles. Growth and health status were monitored during their stay at the rescue center, to ensure adequate development prior to the time of their release.

Manatees selected for release were transported by seaplane and placed into a floating cage $(10 \mathrm{~m} \times 10 \mathrm{~m} \times 3 \mathrm{~m})$ located in the middle zone of the lake. The objective of this soft-release facility was to create an environment similar to the natural habitat, to evaluate the manatees under controlled conditions ${ }^{3}$, and to test the radio tracking equipment. An Advanced Telemetry Systems (ATS, Inc., Isanti, MN) VHF radio-tag $(160 \mathrm{MHz})$, was attached directly to a leather belt around the peduncle of each manatee before placement into the floating cage. Radio-tags utilizing VHF transmission are the best option for monitoring in relatively small areas, such as lagoons or rivers (Marmontel et al., 2012). The acclimatization period lasted three months, during which time the manatees were fed aquatic vegetation collected from the immediate area and kept under close observation. Prior to release, the cage was towed onto the

\footnotetext{
${ }^{3}$ O'Shea, T. and Reynolds III, J.E. (2012) An investigation of factors promoting success or failure of releases of sirenians after being held in captivity, as pertinent to the proposed reintroduction of Antillean manatees (Trichechus manatus manatus) to Guadeloupe. Submitted to Parc National de la Guadeloupe, July 2012. Guadeloupe, Basse-Terre. 51 pp. [Available online at <http://www.guadeloupe-parcnational.fr/IMG/pdf/captif_versus_ sauvage_vol.2.pdf $>$ ]
} 
Table 1. Data of the released manatees, from CREA records.

\begin{tabular}{|c|c|c|c|c|c|}
\hline & Chamo & Quino & Julianna & Cochy & Victoria \\
\hline Gender & Male & Male & Female & Female & Female \\
\hline Origin & Ucayali River & Amazon River & Amazon River & Amazon River & Unknown \\
\hline Status before rescue & Pet & Pet & Pet & Pet & Traded \\
\hline $\begin{array}{l}\text { Place of rescue } \\
\text { (Province) }\end{array}$ & Maynas & $\begin{array}{c}\text { Mariscal } \\
\text { Ramón Castilla }\end{array}$ & Maynas & $\begin{array}{c}\text { Mariscal } \\
\text { Ramón Castilla }\end{array}$ & Maynas \\
\hline $\begin{array}{l}\text { Time spent in captivity } \\
\text { before rescue (approx.) }\end{array}$ & 2 months & 3 months & 24 months & 12 months & 1 week \\
\hline Age group at rescue & Calf & Adult & Juvenile & Juvenile & Calf \\
\hline Weight at rescue & $18.5 \mathrm{~kg}$ & $127 \mathrm{~kg}$ & $46 \mathrm{~kg}$ & $52 \mathrm{~kg}$ & $48 \mathrm{~kg}$ \\
\hline $\begin{array}{l}\text { Time spent } \\
\text { in rehabilitation }\end{array}$ & 28 months & 13 months & 31 months & 13 months & 22 months \\
\hline Age at release (approx.) & 32 months & 73 months & 79 months & 49 months & 34 months \\
\hline Weight at release & $131 \mathrm{~kg}$ & $218 \mathrm{~kg}$ & $138 \mathrm{~kg}$ & $116 \mathrm{~kg}$ & $103 \mathrm{~kg}$ \\
\hline Encounters & 13 & 2 & 21 & 55 & 49 \\
\hline $\begin{array}{l}\text { Tracking days } \\
\text { after release (DAR) }\end{array}$ & 100 & 1 & 91 & 161 & 161 \\
\hline Last record & 28Sep2011 & 20Jul2011 & 19Sep2011 & 28 Nov2011 & $28 \mathrm{Nov} 2011$ \\
\hline
\end{tabular}

beach, where the manatees' physical condition was assessed. Subsequently, the healthy animals were carried on a stretcher for gentle release into the water.

\section{Habitat characterization}

To assess environmental parameters during the tracking period, water depth, water surface temperature, and $\mathrm{pH}$ were daily measured before tracking, between 06:00h and 18:00h at a fixed point located in the middle of the lake. Depth data was also measured and recorded in scattered points of the lake to create bathymetric maps. Three sub periods of environmental variation ( $\mathrm{A}, \mathrm{B}$ and $\mathrm{C}$ ) were defined using the lake's water level variation as a reference: $A=3.0 \mathrm{~m}-2.5 \mathrm{~m}, \mathrm{~B}=2.5 \mathrm{~m}-1.5 \mathrm{~m}$, and $C=1.5 \mathrm{~m}-0.5 \mathrm{~m}$. In order to assess how environmental parameters varied between sub periods, general linear models (GLM) were run in R (version 3.2.2). For each parameter, a separate GLM was run with explanatory variables for sub period and the time of day the environmental variable was recorded. Differences between sub periods were determined using a post hoc Tukey test.

Shore macrophyte cover data was recorded in five sampling periods after release of the manatees, from late July to the end of November. Representative transects were chosen along the shore and adjacent streams. Patches were counted only if they were in contact with water, regardless of the depth, and visually classified by their largest diameter, which ranged from $1-5 \mathrm{~m}, 5-10 \mathrm{~m}, 10-15 \mathrm{~m}, 15-20 \mathrm{~m}$, and $20-25 \mathrm{~m}$. To obtain a reference value of shore macrophyte availability, the percentage of vegetation cover (\% vegetation cover) was estimated for each transect:

$\sum_{i=1}^{I}[$ mean of range $i(m) \times$ patches in range $i \times 100 /$ transect length $(m)]$

The macrophyte composition was noted in each patch, including the plant species identified with the aid of descriptive guides and keys (Albuquerque, 1981; Guterres et al., 2008). A value of 1.0 was given to the species in mono-specific patches. In the case of mixed patches, only the two species with the greatest coverage were noted and termed 'dominant species 1 ' (>50\% of coverage) or 'dominant species 2' (25\% to 50\% of coverage). A value of 0.6 was assigned to 'dominant species 1 ' and 0.4 to 'dominant species 2'. These accumulated values per species were used to estimate the percentages of dominant species cover (e.g. \% species 'A' cover), using the formula:

$\sum_{i=1}^{\mathrm{I}}[$ mean of range $i(m) \times$ accumulated value $($ species $A)$ for patches in range $i \times 100 /$ total length $(m)]$

Floating macrophytes usually form scattered transitory patches of vegetation dragged from shores, and were not evaluated. Cover data was noted only if the vegetation formed stable meadows.

\section{Monitoring of daytime habitat use and behavior}

Daily tracking was conducted between 06:00h and 18:00h, aboard a wooden boat with a $5 \mathrm{HP}$ or $16 \mathrm{HP}$ engine. A threeelement Yagi antenna and a R410 (ATS) receiver were used to detect each manatee's radio-collar frequency according to the 'homing' method (Ryan, 2011; Marmontel et al., 2012). 
Manatees were located within 3-5 meters, using the strongest signal recorded on the receiver without the antenna to better estimate the animal location.

Attempts were made to locate all individuals at least once a day. Relocations of the same individual during the same day were considered for analysis if they had a minimum of two hours difference, considering that such time was sufficient for the animals to relocate themselves (McNay et al., 1994). A Chi square test was performed to determine the independence between time of day (06:00h-10:00h, $10: 00 \mathrm{~h}-14: 00 \mathrm{~h}, 14: 00 \mathrm{~h}-18: 00 \mathrm{~h})$ and the proportion of micro habitat occupied. To illustrate habitat use during the study period, environmental variation data (water depth and vegetation cover) was mapped for each sub period as well as the manatee's location.

The selective use of habitat was determined by a 'usage vs. availability' analysis (Johnson, 1980). This method assigns ranks to the habitat (j) according to the usage (rij) and availability (Sij) for each individual (i), and then calculates the average of the differences between these ranks, through the formula: $\bar{t}_{i}=J^{-1} \sum_{j=1}^{J} t_{i j} \bar{t}_{i}=J^{-1} \sum_{j=1}^{J} t_{i j}$, where tij $=$ rij - sij. A negative $\bar{t}_{i} \bar{t}_{i}$ value indicates preference, while a positive value indicates that use is rare compared to resource availability and points to a possible avoidance (Johnson, 1980). Since only three micro habitats were considered in this study, the $\bar{t}_{i} \bar{t}_{i}$ values rank-orders were used alone to establish the order of selection. The availability of the micro habitats was evaluated according to their relative extent, and the degree of use was obtained based on the number of manatee locations recorded in each micro habitat.

Behavioral observations were made following an ad libitum sampling method (Altmann, 1974) using the changes in signal characteristics received to infer behaviors (Lehner,

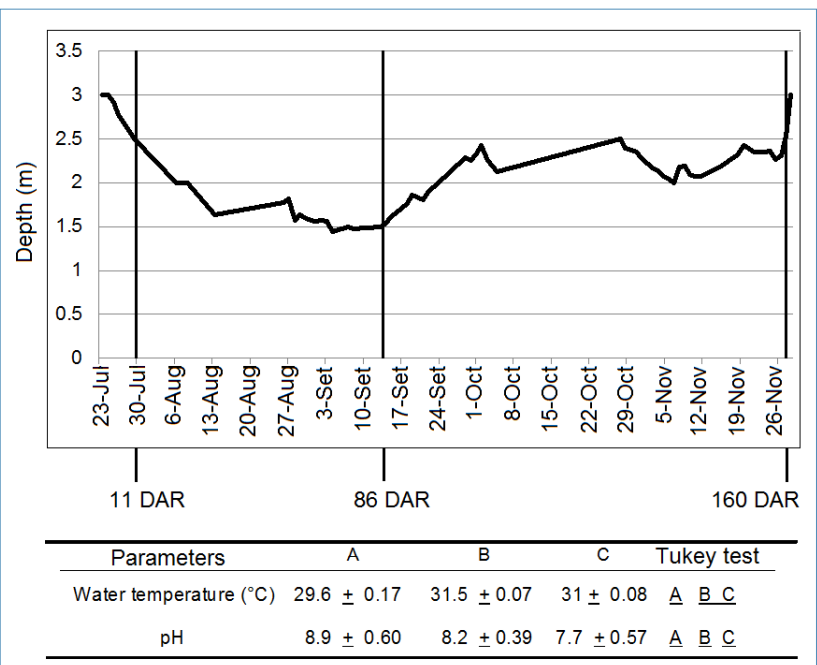

Figure 3. Water level variations at El Dorado Lake. A, B (lowering water levels) and C (rising water level) are considered sub periods. Environmental parameters variations (mean $+\mathrm{SE}$ ) between sub periods are shown. DAR: Days After Release.
1996). Behaviors were grouped under two categories: idling (resting and short movements), and traveling (fleeing and cruising). Individual residence was defined as the occupancy in the release area: \% of occupancy (days) = days of occupancy/ days of tracking $\times 100$ (Castelblanco-Martínez et al., 2013).

\section{Results}

A total of 140 locations were obtained between 19 July and 28 November 2011 (Table 1, Figure 1), on 91 days of tracking. Information on males was omitted from most of the analysis, due to scarcity of data collected from within the study area (Figure 1).

Water depth ranged from 1.4 to $3.0 \mathrm{~m} \quad($ mean $=2.1 \mathrm{~m}$ ) at a fixed point during the study period (Figure 3). Water temperature (glm, adjusted R-squared $=0.31, \mathrm{~F}_{3,85}=14.35, \mathrm{p}<$ 0.001 ) and $\mathrm{pH}$ (glm, adjusted R-squared $=0.48, \mathrm{~F}_{3,85}=27,61$, $\mathrm{p}<0.001$ ) were significantly associated with both time and sub period. Sub periods differed significantly in terms of water temperature (Tukey; A-B, $\mathrm{p}<0.01$; A-C, $\mathrm{p}<0.05$; B-C, $\mathrm{p}>0.05$ ) and $\mathrm{pH}$ (Tukey; A-B, $\mathrm{p}<0.01$; $\mathrm{A}-\mathrm{C}, \mathrm{p}<0.01$; B-C, $\mathrm{p}<0.01$ ) (Figure 3).

The highest percentage of macrophyte cover was recorded at the beginning and at the end of the study period (Table 2, Figure 4). Pontederia rotundifolia was the dominant species, mainly distributed along the northern part of the lake. In the south, pastures were abundant and composed mostly by Paspalum repens and Echinochloa polystachya.

Female manatee micro habitat preference was as follows in order of highest to lowest preference: Floating macrophytes $\quad\left(\bar{t}_{i} \bar{t}_{i}=-1.667\right)$, Open water $\left(\bar{t}_{i} \bar{t}_{i}=0.667\right)$ and Shore macrophytes $\left(\bar{t}_{i} \bar{t}_{i}=1\right)$. The percentages of micro habitat used by females during sub periods A, B, and C are illustrated in Figure 4.

Open water comprised most of the study area while Floating vegetation had the lowest coverage, mainly restricted to meadows of $P$. stratiotes in a portion of Anuncho channel. Shore vegetation cover decreased along with water depth, (Junk et al., 1989; Bayley, 1995; Piedade et al., 2010), but floating macrophytes maintained a stable coverage in Anuncho channel (Figure 4). Micro habitat availability ranks did not vary during the study.

A total of 2221 minutes of observation were made. Idling behavior (78\%) surpassed traveling (22\%), suggesting that manatees spent most of their time resting or performing short displacements. Percentages of idling for each manatee were as follow: Chamo (82\%), Julianna (82\%), Victoria (77\%) and Cochy (76\%). No relationship between sighting hour and sighting location (micro habitat type) was detected (Chi square, $\chi^{2}=3.813, \mathrm{p}>0.01$ ) (Table 3). Few data were obtained from males because both individuals left the lake during sub period A. Quino's transmitter signal was lost two days after release. Chamo stayed in the lake for 11 days, and subsequent data were omitted from the analysis because the animal remained entrapped in a low water section of Dorado 
Table 2. Percentage of vegetation cover and dominant species observed between July and November in 2011. P. ro: Pontederia rotundifolia, E. po: Echinochloa polystachya, E. cr: Eichhornia crassipes, P. re: Paspalum repens.

\begin{tabular}{|l|c|c|c|c|c|c|c|}
\hline Transition & $\begin{array}{c}\text { Length } \\
\text { evaluated (m) }\end{array}$ & $\begin{array}{c}\text { Length } \\
\text { covered }(\mathbf{m})\end{array}$ & $\begin{array}{c}\text { Cover } \\
\%\end{array}$ & $\begin{array}{c}\text { Dominant } \\
\text { species 1 }\end{array}$ & $\%$ & $\begin{array}{c}\text { Dominant } \\
\text { species 2 }\end{array}$ & $\%$ \\
\hline Jul - Aug & 7281 & 1871.5 & 25.7 & P. ro & 60.2 & E. po & 16.6 \\
\hline Aug - Sep & 9701 & 1092.5 & 11.3 & P. ro & 36.0 & E. po & 17.3 \\
\hline Sep - Oct & 5207 & 826.5 & 15.9 & P. ro & 34.8 & P. re & 11.7 \\
\hline Oct - Nov & 10248 & 2371 & 23.1 & P. ro & 37.6 & E. cr & 10.6 \\
\hline Nov - Dec & 10062 & 2720.5 & 27.0 & P. ro & 43.2 & E. po & 10.6 \\
\hline
\end{tabular}

channel and was not able to change location due to shallow areas that blocked its path. Chamo's transmitter was found upstream of the previous location point 100 days after release (DAR; Figure 1a), indicating that when the water level rose, Chamo returned to the lake. All females had 100\% residence time within the study area. The percentages of time spent in behavioral categories are shown in Figure 5.

\section{Discussion}

One of the criteria for a successful release is that animals are able to locate food and to remain in habitat systems with suitable characteristics for survival (Lima et al., 2007). The tracked female manatees used the available micro habitat selectively and preferred areas with floating vegetation, which provides food and shelter. This tendency was also observed by Montgomery et al. (1981) and Arraut et al. (2009) on Amazonian manatees and is likely characteristic of all sirenians.

Shore macrophytes were the least preferred micro habitat despite its high coverage in the study area, and the dominant aquatic shore macrophytes being previously reported as preferred food items of the Amazonian manatee diet (Colares and Colares, 2002; Franzini et al., 2013; Guterres-Pazin et al., 2014). Sirenians are generally opportunistic in their feeding habits (Best, 1981; Castelblanco-Martínez et al., 2009), however their diet becomes more selective when food sources are abundant (Colares and Colares, 2002) as recorded in the lake, which could explain the preference for floating macrophytes, as $P$. stratiotes was dominant in this micro habitat and also the main food item supplied to manatees during their rehabilitation.

Selecting floating vegetation could have some advantages over selecting shore macrophytes. Floating macrophytes were more typically found in deeper areas than shore macrophytes. Shallow areas may restrict the manatees' maneuvering and therefore could be avoided at certain times. Habitat selection has been linked to water depth, as observed by Charry (2002) on a semi captive $T$. inunguis. During the lowering-water period, caimans were often observed associated with shore vegetation. Aggregation of predators, such as caimans, could be a cause for manatees' avoidance of potential interaction during the beginning of the low-water level season (Arraut et al., 2009). Likewise, African manatees have been observed avoiding macro habitat where crocodiles are abundant, thought to minimize encounters with these potential predators (Luiselli et al., 2012), but this hypothesis has not been tested and remains as speculation.

The migratory movements of the tracked individuals were as expected for the low-water season, when manatees migrate from seasonally flooded zones into deep water channels and permanent lakes (Arraut et al., 2009). Females showed higher level of residence than males, and stayed within the release area, while males left the lake during the season of loweringwater levels. In West Indian manatees (Trichechus manatus), site fidelity appears to be stronger in females than in males, suggesting that the dispersal of males is a strategy to increase the chances of meeting sexually receptive females (Deutsch et al., 2003; Self-Sullivan et al., 2003; Castelblanco et al., 2013). This may also be the case for Amazonian manatees, as genetic evidence supports male-biased dispersal (Satizábal et al., 2012). Although our sample size is too small to conclude on behavioral differences due to the individual sex, our results suggest gender differences.

Manatees spent most of the time performing idling behaviors (probably resting, moving calmly, or feeding), which agrees with observations in captivity ${ }^{4}$ (Castelblanco-Martínez, 2000) and semi-captivity (Charry, 2002). In general, traveling took place in open water areas used as corridors between feeding areas. In contrast, most idling behaviors occurred in areas with floating macrophytes. Habitat selection did not indicate any diurnal activity pattern, however temporal activity patterns have been observed in T. manatus manatus (Castelblanco et al., 2015), suggesting that more information regarding $T$. inunguis nocturnal activities need to be collected.

The results suggest that female manatees began to adapt to their natural environment, preferring areas with floating vegetation, advantageous in terms of providing food and shelter. The observations recorded in terms of behavior and

${ }^{4}$ Arévalo-Sandi, A., Pezo-Díaz, R. and Castelblanco-Martínez, D.N. (2010) Estudio del comportamiento de una cría de Trichechus inunguis en cautiverio. Page 81 in Abstracts. II Congreso de la Sociedad Peruana de Mastozoologia, 12-16 November 2010, Arequipa, Peru. 


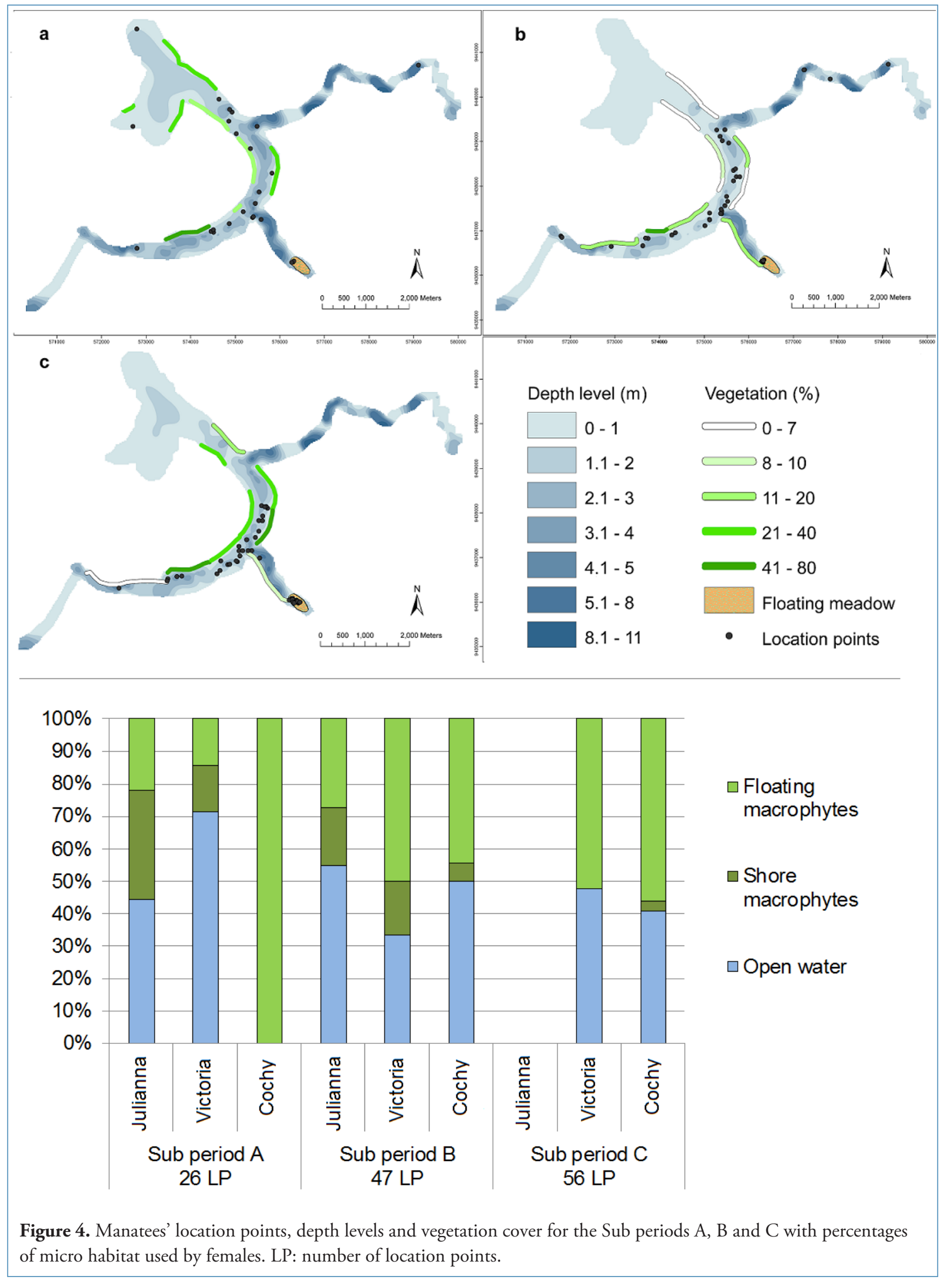




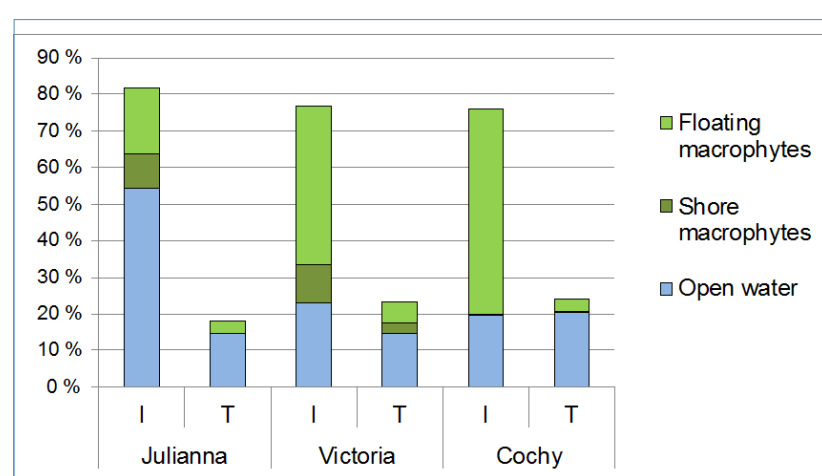

Figure 5. Percentage of time spent in behavioral categories Idling (I) and Traveling (T).

habitat use are also indicators of progress, as they resemble previous reports for the species both in captivity and in natural habitat (IUCN/SSC, 2013). During our tracking efforts, we did not observe any manatee approaching the boats, and we even registered some fleeing events. In the case of the males, although they left the lake and additional information about habitat use could not be collected, their migration fits into the expected behavior for male manatees, and the lack of evidence of death or injuries may also suggest that they have adapted as well.

The information acquired from manatees at this first release program in Peru is valuable because it allows us to identify the strengths and weaknesses in the selection criteria for suitable candidates and release and post release monitoring efforts, thereby enhancing future releases within an ongoing rehabilitation program. Release area and time are decisive elements to facilitate the adaptation of rehabilitated manatees back into the wild. The chosen release area was under national protection and included adequate deep conditions, connectivity, and ample food reserves. Manatees were released during the lowering-water period, and connections with larger waterways were naturally closed within a few days of the beginning of the monitoring period. This was thought to restrict connectivity, however, did not stop males from leaving the monitoring area and resulted in a very short tracking period for those individuals. We suggest that further releases should be performed when the water level no longer allows connections to major waterways, giving the monitoring team time to assess the condition of the released manatees into the wild.

The acclimatization period in a soft release enclosure is also important and should be maintained (Normande et al., 2014), because it allows researchers to incorporate vegetable species from the release area into the manatees' diet, and exposes the animals to the natural conditions. Manatee rehabilitation programs should be improved by including a mixed diet of natural vegetative species during the rehabilitation process.

Age and time in captivity also must be considered in choosing a suitable animal for release (CastelblancoMartínez, 2013; Normande et al., 2014). Since habitat use
Table 3. Number of location points per micro habitat at hourly intervals.

\begin{tabular}{|l|c|c|c|c|}
\hline Intervals & $\begin{array}{c}\text { Floating } \\
\text { macrophytes }\end{array}$ & $\begin{array}{c}\text { Shore } \\
\text { macrophytes }\end{array}$ & $\begin{array}{c}\text { Open } \\
\text { Water }\end{array}$ & Total \\
\hline 06:00 - 10:00 & 18 & 7 & 12 & 37 \\
\hline 10:00 - 14:00 & 21 & 3 & 20 & 44 \\
\hline 14:00 - 18:00 & 21 & 8 & 23 & 52 \\
\hline Total & 60 & 18 & 55 & 133 \\
\hline
\end{tabular}

and foraging strategies are decisive for animal survival, the species' cognitive capacities play a crucial role (CastelblancoMartínez, 2010). It is not recommended to release individuals that have spent a long time in captivity or those who have been rescued as young calves only a few months in age, as most experienced manatees are more likely to survive after the release ${ }^{2}$ (Adimey et al. 2012). The early years that calves spend with their mothers are vital for learning to meet the complexity of survival challenges, thus providing them with experience on locating forage and resources, and determining the timing and complexity of migration. This possibly explains why Chamo, being less experienced as he was rescued at a younger age than Quino, did not leave the release area in time to reach a major stream, and remained in an isolated pond during the season of low-water.

Despite the evidences of success in this release, the recovery of the Amazonian manatee cannot rest solely on the efforts of rehabilitation programs. Illegal hunting and capture of T. inunguis persists in Peru, even within protected areas (Soto, 2007). From 2007 to 2017, CREA has rescued 40 Amazonian manatees, 20 as orphaned calves ${ }^{5}$. Since orphaned calves are a collateral consequence of separation from the mother, the relatively large number of rescued calves may be an indicator of high current levels of poaching on lactating females. Although environmental education programs are being successfully conducted by CREA with the support of the regional government, additional national and regional strategies should be developed in order to control hunting and other threats. People awareness about the need for conserving this species is important, but cooperation between stakeholders, local authorities, researchers, park rangers, and other engaged people is necessary to ensure the continuity of the Amazonian manatee population in Peru.

J. Velásquez, pers. comm. 


\section{Acknowledgments}

This research project was funded and supported by the Dallas World Aquarium Zoo. We also counted on support from the Centro de Rescate Amazónico, Pacaya Samiria National Reserve (National Service of Protected Areas of Peru), and the Ministry of Production, Loreto. We are very grateful to all who made the rehabilitation and release of Amazonian manatees in Peru possible: Daryl Lee Richardson, Luis Sigler, Javier Velásquez, Marcial Perea, Juan Sánchez, Harold Portocarrero, Darwin Loja, Kelly Tapayuri, Cristian Vélez, Solange García, the Social Organization of Artisanal Fishermen 'Yacu Tayta', park rangers, and many students and volunteers. Special thanks to Julie Day for the review of the language and the statistical advices. We are also very grateful to all the anonymous reviewers for their comments to improve the manuscript.

\section{References}

Adimey, N.M., Mignucci-Giannoni, A., Auil Gomez, N., Da Silva, V.M.F., De Carvalho, C.M., Morales Vela, B., De Lima, R.P. and Rosas, F.C.W. (2012) Manatee rescue, rehabilitation, and release efforts as a tool for species conservation. Pages 205-217 in Hines, E., Reynolds, J., Aragones, L., MignucciGiannoni, A.A. and Marmontel, M. (Eds) Sirenian Conservation: Issues and Strategies in Developing Countries. University Press of Florida, Florida, USA.

Albuquerque, B. (1981) Plantas forrageiras da Amazônia: I aquáticas flutuantes livres. Acta Amazonica 11(3): 457- 471. https://doi.org/10.1590/1809-43921981113457

Altmann, J. (1974) Observational study of behavior: Sampling methods. Behavior 49(3): 227-267. https://doi.org/10.1163/ 156853974X0053410.1163/156853974X00534

Arraut, E.M., Marmontel, M., Mantovani, J.E., Novo, E., Macdonald, D.W. and Kenward, R.E. (2009) The lesser of two evils: seasonal migrations of Amazonian manatees in the Western Amazon. Journal of Zoology 280(3): 247-256. https://doi.org/10.1111/j.1469-7998.2009.00655.x

Barrows, E. (2001) Animal behavior desk reference; a dictionary of animal behavior, ecology and evolution. 2.ed. CRC Press, Florida, USA.

Bayley, P. (1995). Understanding large river: floodplain ecosystems. Bioscience 45(3): 153-158.

https://doi.org/10.2307/1312554

Best, R.C. (1981) Foods and feeding habits of wild and captive Sirenia. Mammal Review 11(1): 3-29. https://doi.org/10.1111/j.1365-2907.1981.tb00243.x

Castelblanco-Martínez, D.N. (2000) Estudio del comportamiento de un juvenil de manatí amazónico (Trichechus inunguis) en cautiverio (Puerto Nariño, Amazonas, Colombia). B.Sc. Thesis. Universidad Nacional de Colombia, Bogotá, Colombia. 195 pp.
Castelblanco-Martínez, D.N. (2004) Estudio del comportamiento en vida silvestre del manatí del Orinoco (Trichechus manatus). Pages 113-131 in Diazgranados, M.C. and Trujillo, F. (Eds) Fauna Acuática en la Orinoquía Colombiana. Instituto de Estudios Ambientales para el Desarrollo - Departamento de Ecología y Territorio, Bogotá, Colombia.

Castelblanco-Martínez, D.N. (2010) Capacidades cognoscitivas, estrategias de forrajeo y estructura social: el caso de los mamíferos acuáticos. Revista Colombiana de Ciencia Animal 2(2): 270-286.

Castelblanco-Martínez, D.N., Ed. (2013) Capture, rehabilitation and release of manatees - Protocols. Parc National de la Guadeloupe, France.

Castelblanco-Martínez, D.N., Morales-Vela, B., HernándezArana, H.A. and Padilla-Saldívar, J. (2009) Diet of manatees Trichechus manatus manatus in Chetumal Bay, Mexico. Latin American Journal of Aquatic Mammals 7(1-2): 39-46.

https://doi.org/10.5597/lajam00132

Castelblanco-Martínez, D.N., Padilla-Sáldivar, J., Hernández-Arana, H.A., Slone, D., Reid, J. and MoralesVela, B. (2013) Movement patterns of Antillean manatees in Chetumal Bay (Mexico) and coastal Belize: A challenge for regional conservation. Marine Mammal Science 29(2): 166182. https://doi.org/10.1111/j.1748-7692.2012.00602.x

Castelblanco-Martínez, D.N., Morales-Vela, B., Slone, D.H., Padilla-Saldívar, J.A., Reid, J.P. and Hernández-Arana, H.A. (2015) Inferring spatial and temporal behavioral patterns of free-ranging manatees using saltwater sensors of telemetry tags. Mammalian Biology-Zeitschrift für Säugetierkunde 80: 21-30. https://doi.org/10.1016/j.mambio.2014.07.003

Charry, A. (2002) Patrones de comportamiento y uso de hábitat del manati amazónico (Trichechus inunguis) en condiciones de semicautiverio. B.Sc. Thesis. Universidad Nacional de Colombia, Colombia. 102 pp.

CMS (2012) Appendices I and II of the Convention on the Conservation of Migratory Species of Wild Animals. Available online at <www.cms.int/sites/default/files/instrument/ appendices_s.pdf>. Consulted on 23 June 2013.

Colares, I.G. and Colares, E.P. (2002) Food plants eaten by Amazonian manatees (Trichechus inunguis, Mammalia: Sirenia). Brazilian Archives of Biology and Technology 45(1): 6772. https://doi.org/10.1590/S1516-89132002000100011

Deutsch, C.J., Reid, J.P., Bonde, R.K., Easton, D.E., Kochman, H.I. and O'Shea, T.J. (2003) Seasonal movements, migratory behavior, and site fidelity of West Indian manatee along the Atlantic coast of the United States. Wildlife Monographs 151: 1-77. 
Domning, D. (1982) Commercial exploitation of manatees Trichechus in Brazil c. 1785-1973. Biological Conservation 22(2): 101-126.

https://doi.org/10.1016/0006-3207(82)90009-X

Franzini, A., Castelblanco-Martínez, D.N., Rosas, F.C.W. and Da Silva, V.M.F. (2013) What do local people know about Amazonian manatees? Traditional Ecological Knowledge of Trichechus inunguis in the Oil Province of Urucu, AM, Brazil. Natureza \& Conservação 11(1): 75 - 80.

https://doi.org/10.4322/natcon.2013.012

Guterres, M.G., Marmontel, M., Ayub, D., Singer, R.F. and Singer, R.B (2008) Anatomia e morfologia de plantas aquáticas da Amazônia utilizadas como potencial alimento por peixe-boi amazônico. 1.ed. Instituto de Desenvolvimento Sustentável Mamirauá, Belém, Brazil.

Guterres-Pazin, M.G., Marmontel, M., Rosas, F.C.W., Pazin, V.F.V. and Venticinque, E.M. (2014) Feeding ecology of the Amazonian manatee (Trichechus inunguis) in the Mamirauá and Amanã Sustainable Development Reserves, Brazil. Aquatic Mammals 40(2): 139-149. https://doi.org/10.1578/AM.40.2.2014.139

IUCN (2014) The IUCN Red List of Threatened Species Version. 2014.3. Available online at <www.iucnredlist.org>. Consulted on 2 May 2014.

IUCN/SSC (2013) Guidelines for Reintroductions and Other Conservation Translocations. IUCN Species Survival Commission, Gland, Switzerland.

Johnson, D. (1980) The comparison of usage and availability measurements for evaluating resource preference. Ecology 61(1): 65-71. https://doi.org/10.2307/1937156

Junk, J.W., Bayley, P.B. and Sparks, R.E. (1989) The flood pulse concept in river floodplain systems. Pages 110-127 in Dodge, D.P. (Ed.) Proceedings of International Large River Symposium. Canadian Special Publications of Fisheries and Aquatic Sciences, Ottawa, Canada.

Kleiman, D.G. (1989) Reintroduction of captive mammals for conservation. Bioscience and Microflora 39: 152-161. https://doi.org/10.2307/1311025

Lehner, P.N. (1996) Handbook of Ethological Methods. 2.ed. Cambridge University Press, Cambridge, U.K.

Lima, R.P., Alvite, C.M.C. and Vergara-Parente, J.E. (2007) Protocolo de Reintroduçáo de Peixes-boi Marinhos no Brasil. 1.ed. IBAMA-Maranhão \& Instituto Chico Mendes, São Luís, Brazil.

Luiselli, L., Akani, G.C., Ebere, N., Angelici, F.M., Amori, G. and Politano, E. (2012) Macro-habitat preferences by the African manatee and crocodiles - ecological and conservation implications. Web Ecology 12: 39-48.

https://doi.org/10.5194/we-12-39-2012
Marmontel, M., Odell, D.K. and Reynolds, J.E. (1992) Reproductive biology of South American manatees. Pages 295-312 in Hamlett, W.C. (Ed.) Reproductive Biology of South American Vertebrates. Springer-Verlag, New York, USA. https://doi.org/10.1007/978-1-4612-2866-0_2

Marmontel, M., Reid, J., Sheppard, J.K. and Morales-Vela, B. (2012) Tagging and movements of sirenians. Pages 116-125 in Hines, E., Reynolds, J., Aragones, L., Mignucci-Giannoni, A.A. and Marmontel, M. (Eds) Sirenian Conservation: Issues and Strategies in Developing Countries. University Press of Florida, Florida, USA.

Martin, A.R. and Da Silva, V.M.F. (1998) Tracking aquatic vertebrates in dense tropical forest. MTS Journal 32(1): 8288.

McNay, R.S., Morgan, J.A. and Bunnell, F.L. (1994) Characterizing independence of observations in movements of Columbian black-tailed deer. Journal of Wildlife Management 58(3): 422-429. https://doi.org/10.2307/3809312

Montgomery, G.G., Best, R.C. and Yamakoshi, M. (1981) A radio-tracking study of the Amazonian manatee Trichechus inunguis (Mammalia:Sirenia). Biotropica 13(2): 81-85. https://doi.org/10.2307/2387708

Normande, I.C., Luna, F.O., Malhado, A.C.M., Borges, J.C.G., Viana Junior, P.C., Attademo, F.L.N. and Ladle, R.J. (2014) Eighteen years of Antillean manatee Trichechus manatus manatus releases in Brazil: lessons learnt. Oryx FirstView 1-7. https://doi.org/10.1017/S0030605313000896

Perea-Sicchar, C.M., Velásquez-Varela, L.J., SánchezBabilonia, J., Espinoza-Azan, M., Richardson, D.L. and Sigler, L. (2011) Manejo y rehabilitación del manatí amazónico (Trichechus inunguis) en el Perú. Ciencia Amazónica 2(1): 1524. https://doi.org/10.22386/ca.v1i2.11

Piedade, M.T.F., Ferreira, C.S. and Franco, A.C. (2010) Estrategias reproductivas de la vegetación y sus respuestas al pulso de la inundación en las zonas inundables de la Amazonía Central. Ecosistemas 19(1): 52-66.

Rojas, G., Noriega, J., OSPPA-UPC YACU TAYTA (Organización social de pescadores y procesadores artesanales 'Yacu Tayta') (2006) Plan de Manejo de Arapaima gigas "paiche" en la cocha El Dorado, Cuenca Yanayacu Pucate - Reserva Nacional Pacaya Samiria (2004 -2008). 1.ed. ProNaturaleza, The Nature Conservancy, USAID, Lima, Peru.

Rosas, F.C.W. (1994) Biology, conservation and status of the Amazonian manatee Trichechus inunguis. Mammal Review 24(2): 49-59. https://doi.org/10.1111/j.1365-2907.1994. tb00134.x

Ryan, J. (2011) Mammalogy Techniques Manual. 2.ed. Lulu, Raleigh, USA. 
Satizábal, P., Mignucci-Giannoni, A., Duchêne, S., CaicedoHerrera, D., Perea-Sicchar, C., García-Dávila, C., Trujillo, F. and Caballero, S. (2012) Phylogeography and sex-biased dispersal across riverine manatee populations (Trichechus inunguis and Trichechus manatus) in South America. PLoS ONE 7(12): e52468.

https://doi.org/10.1371/journal.pone.0052468

Self-Sullivan, C., Smith, G.W., Packard, J.M. and La Commare, K.C. (2003) Seasonal occurrence of male Antillean manatees (Trichechus manatus manatus) on the Belize Barrier Reef. Aquatic Mammals 29 (3): 342-354.

https://doi.org/10.1578/01675420360736514

Soto, A. (2007) Caza del manatí amazónico en la Reserva Nacional Pacaya Samiria. Centro de Datos para la Conservación, Universidad Nacional Agraria la Molina, Lima, Peru.
Timm, R.M., Albuja, L. and Clauson, B.K. (1986) Ecology, distribution, harvest and conservation of the Amazonian manatee, Trichechus inunguis, in Ecuador. Biotropica 18(2): 150-156. https://doi.org/10.2307/2388757

Vásquez, P. and Tovar, C. (2007) La fauna silvestre en la Reserva Nacional Pacaya Samiria: Una guia para el manejo comunal. 1.ed. Centro de Datos para la Conservación- Universidad Nacional Agraria la Molina, ProNaturaleza, The Nature Conservancy, USAID, Lima, Peru. 